УДК 341.218 .3

DOI https://doi.org/10.51989/NUL.2021.4.12

\title{
30 РОКІВ НЕЗАЛЕЖНОСТІ УКРАЇНИ: МІЖНАРОДНО-ПРАВОВІ АСПЕКТИ ПРАВОНАСТУПНИЦТВА ДЕРЖАВИ
}

\section{Мамонтов Ігор Олександрович,}

кандидат юридичних наук, заслужений юрист України, доцент кафедри політичних наук і права

Київського національного університету будівництва і архітектури

У статті досліджено особливості інституту правонаступництва держав у доктринах українських і зарубіжних вчених, законодавчих актах і у практиці реалізації на прикладах держав. У дослідженні використано порівняльно-правовий і формально-догматичний методи, а також метод історико-правового дослідження. Доведено, що за 30 років незалежності в Україні не реалізовано політико-правову складову правонаступництва держави у контексті визнання України правонаступником державних утворень періоду 1917-1920 рр, що зараз є ґрунтом зазіхань на суверенітет і територіальну цілісність України. Показано дискусії вчених щодо розуміння інституту правонаступництва, які зосереджені в основному навколо правонаступництва щодо міжнародних договорів, а також правонаступництва держав щодо майна, надано характеристику міжнародно-правовим і національним актам регулювання реалізації правонаступництва. Представлено авторське бачення поняття правонаступництва держави. За допомогою порівняльно-правового методу досліджено практику реалізації інституту правонаступництва у таких державах, як Латвія, Литва, Естонія, Азербайджан, Грузія і Україна. Цей порівняльно-правовий та історико-правовий аналіз засвідчив, що згадані держави, окрім України, у своїх конституційних і декларативних актах при поновленні державності одразу закріпили статус правонаступництва за національними державними утвореннями початку XX СТ., засудили окупацію СРСР їхніх територій та вказали іншу інформацію про національні уряди, які продовжили державотворчу діяльність в еміграції періоду окупації СРСР. Надано характеристику актів поновлення державності цих країн у контексті визнання етапів національного державотворення як предмету правонаступництва держав. За допомогою формально-догматичного методу було проаналізовано вітчизняне законодавство у даній сфері, у результаті чого констатовано необхідність внесення змін і доповнень у Конституцію України щодо закріплення правонаступництва України не від УРСР, а від національних державних утворень періоду визвольних змагань 1917-1920 рр. Представлено перспективи подальших досліджень щодо удосконалення законодавчого закріплення правонаступництва України.

Ключові слова: правонаступництво держав, міжнародно-правовий договір, державотворення, поновлення держави, нова незалежна держава.

\section{Mamontov Ihor. 30 years of independence of Ukraine: international legal aspects of the succession of the state}

The article examines the features of the institution of succession of states in the doctrines of Ukrainian and foreign scientists, legislative acts and in the practice of implementation on the examples of countries. The study used comparative legal and formal dogmatic methods, as well as the method of historical and legal research. It has been proved that over 30 years of independence in Ukraine, the political and legal component of the state's succession has not been implemented in the context of recognizing Ukraine as the legal successor of state entities of the period 1917-1920, which is now the ground for encroachments on the sovereignty and territorial integrity of Ukraine. Discussions of scholars to the understanding of the institution of succession are shown, which are mainly concentrated around legal succession in relation to international treaties, as well as the succession of states in relation to property, characterized by international legal and national acts of regulation of the implementation of succession. The author's vision of the concept of legal succession of the state is presented. Using the comparative legal method, the practice of implementing the institution of succession in such states as Latvia, Lithuania, Estonia, Azerbaijan, Georgia and Ukraine has been studied. This comparative legal and historical legal analysis showed that the aforementioned states, except for Ukraine, in their 
constitutional and declarative acts, upon the restoration of statehood, immediately consolidated the status of succession to national state formations of the early 20th century, condemned the occupation of their territories by the USSR and other information about national governments. who continued their state activities in the emigration of the period of the occupation of the USSR. The acts of renewal of the statehood of these countries are characterized in the context of the recognition of the stages of the national state as the subject of the legal succession of states. With the help of the formal dogmatic method, the domestic legislation in this area was analyzed, as a result of which it was stated that it was necessary to make changes and additions to the Constitution of Ukraine regarding the consolidation of the legal succession of Ukraine not from the Ukrainian SSR, but from the national state formations of the period of the liberation struggle of 1917-1920. The prospects for further research on improving the legislative consolidation of the legal succession of Ukraine are presented.

Key words: legal succession of states, international legal treaty, states, state renewal, new independent state.

Актуальністьтеми, постановка проблеми. Присвячуючи цю статтю 30-річчю проголошення незалежності України, насамперед потрібно зазначити, що Українська Держава у XXI ст. офіційно визначилася із остаточним цивілізаційним вибором, що стало наслідком внутрішньополітичної кризи 2010-2014 рр., а також воєнного вторгнення Російської Федерації та окупації частини української суверенної території, чим було порушено міжнародні безпекові норми і геополітичне статус-кво в Європі та у світі загалом. Цивілізаційний вибір України став детермінантою політичної зрілості нації і продемонстрував міжнародній спільноті цінності українського суспільства - демократію, права людини та прагнення до цивілізованого поступу, що виразилося у конституційному закріпленні вектору європейської і євроатлантичної інтеграції. Водночас зовнішньополітичний вплив на український політикум та суспільну свідомість, що здійснюється передусім Російською Федерацією, спрямований сконцентрувати всі зусилля на недопущення виходу з-під безпосереднього впливу Росії Української Держави. У цьому контексті остання стаття Президента РФ В. Путіна «Про історичну єдність росіян та українців» [1] продемонструвала чіткий наратив, де обстоюється твердження про той факт, що Україна є продуктом СРСР, свідомо іґноруються попередні етапи державотворення, наводяться упереджені аргументи про «історичну єдність» українського і російського народів та інші політико-маніпулятивні факти, що обмежують тяглість українського державотворення рамками тридцятиріччя. Зважаючи на значну суспільно-політичну і наукову актуальність проблеми осмислення реальних етапів українського державотворення, що $€$ важливим фактором консолідації українського суспільства, очевидною $\epsilon$ наукова потреба звернення до політикоправових аспектів правонаступності етапів українського державотворення протягом XX ст. Дослідження цієї проблеми важливе з точки зору осмислення окцидентального вектору розвитку українського суспільства, що знайшло своє практичне вираження у процесах європейської інтеграції. Загалом, питання тяглості українського державотворення в умовах воєнно-політичного зазіхання на суверенітет і територіальну цілісність України переходить у площину національної та міжнародної безпеки на європейському континенті. На додачу, недостатня врегульованість як на міжнародному, так і на національному рівні питання про правонаступництво України актуалізує дослідження даної проблеми у сучасних історико-правових і політикоправових студіях.

Стан наукової розробки проблеми. Дослідженням особливостей правонаступництва України після розпаду СРСР займалися такі вітчизняні науковці, як О.С. Бакумов, А.В. Войціховський, В.О. Галан, В.Н. Денисов, К.Е. Маілунц, А.Я. Мельник, Ю.О. Ноговіцина, О.Ю. Перевезенцев, О.3. Ярошко та інші дослідники. Зарубіжні вчені також приділили значну увагу даній проблематиці, серед яких слід згадати насамперед Д.П. О'Конела та М. Кравена, які сформували характеристики міжнародно-правового режиму правонаступництва, запропонували перспективи удосконалення даного політико-правового інституту. Водночас слід зазначити, що 
дослідники цього політико-правового феномену приділили свою увагу в основному аналізу особливостей правонаступництва за договорами чи майном попередніх держав новими або поновленими державами. Недослідженими залишаються питання щодо політико-правового правонаступництва держав щодо попередніх державотворчих періодів, коли держави втрачали свій суверенітет унаслідок воєнної окупації і поновлювали його через декілька десятиліть, що характерно для багатьох держав колишнього СРСР і України зокрема. Тут акцент дослідження концентрується на визнанні факту державності попередніх періодів та його значення для статусу поновленої або новоутвореної держави.

Мета і завдання статті. Метою даної статті $€$ дослідження позицій вчених щодо міжнародно-правових особливостей інстиуту правонаступництва держави, характеристика міжнародного і національного законодавства та практики його реалізації. Завдання статті - 3 урахуванням 30-річного періоду державного будівництва формування науково обґрунтованих рекомендацій щодо уточнення правонаступництва України по відношенню до попередніх етапів державотворення.

Результати досліджень. Правонаступництво української державності, на наше переконання, виступає самостійним політико-правовим інститутом, який базується на нормах міжнародного і національного права, що виражається у прийнятті державою прав і обов'язків державних утворень, правонаступником яких проголошується держава, переходом встановлених міжнародними договорами прав і обов'язків від однієї держави до іншої з урахуванням основних принципів міжнародного права стосовно територій, які $\epsilon$ об'єктом правонаступництва держав.

У цьому контексті підтримуємо думку А.В. Войціховського і О.С. Бакумова про те, що правонаступництво держав виникає у тому разі, якщо відбувається остаточна і безповоротна заміна суверенітету однієї держави над тією або іншою територією суверенітетом іншої держави. На переконання вказаних авторів, міжнародне право пов'язує правонаступництво лише зі зміною території. Але не лише держава, а й об'єднання держав, що володіє міжнародною правосуб'єктністю, може отримати або втратити яку-небудь територію. Особливого значення питання правонаступництва набувають при виникненні нових незалежних держав у результаті: національно-визвольної боротьби; повного роз'єднання існуючої держави; відокремлення частини держави; злиття існуючих держав тощо. Тож у міжнародному праві виділяють такі підстави правонаступництва: за об'єднання існуючих держав; за поділу держав; за відокремлення частини держави; за переходу частини території держави до іншої держави; зза повного зникнення (ліквідації) однієї держави як суб'єкта міжнародного права і виникнення на її місці інших держав [2, с. 108].

Існують також нетрадиційні підходи до правонаступництва держав, запропоновані Д.П. О'Конелом та М. Кравеном [3; 4]. Розробляючи ці підходи, вчені намагались забезпечити і обґрунтувати континуїтет міжнародних прав та обов'язків держав при правонаступництві. О'Конел закликав відмовитись від критерію правосуб'єктності і керуватись принципом континуїтету в інтересах міжнародного правопорядку. М. Кравен пропонував розмежувати поняття «правосуб'єктність» та «ідентичність» i, звівши правонаступництво до змін в ідентичності, забезпечити континуїтет міжнародних зобов'язань. У цьому контексті Ю.О. Ноговіциною запропоновано об'єднати і розвинути ці два підходи шляхом визнання принципу континуїтету складовою принципу pacta sunt servanda і зумовити виключення з нього ступеня ідентичності держав-наступниць державіпопередниці [5, с. 124].

У цьому розумінні варто навести думку О.Ю. Перевезенцева, який справедливо зазначає, що, оскільки зазначені правовідносини складають частину загальних міждержавних відносин, суб'єктами правового зв'язку виступають держави взагалі, при цьому для суб'єктного складу інституту правонаступництва характерний поділ на основні суб'єкти (державапопередниця і держава-правонаступниця, якою виступає правомірно створена нова держава) і додаткові суб'єкти (будь-які інші треті держави - їхні контрагенти) $[6$, c. 8]. В охарактеризованій ознаці звер- 
тає на себе увагу формулювання «...правомірно створена нова держава...», що не співвідноситься із правомірністю створення УСРР/УРСР із подальшою інкорпорацією до СРСР, тому правонаступництво України від державного утворення, що утворене неправомірним шляхом, не узгоджується із охарактеризованою вище правовою ознакою інституту правонаступництва держав.

Потрібно зазначити, що аналіз міжнародних актів і національного законодавства засвідчує наявність різних сфер регулювання правонаступництва, серед яких можна виділити регулювання щодо зобов'язань по договорах, наприклад, щодо власності на державні установи, щодо боргової відповідальності, а також щодо архівної власності та інших об'єктів власності держав. Водночас, на наше переконання, первинне місце у класифікації сфер регулювання тут має займати такий об'єкт регулювання, як правонаступництво щодо попередніх етапів державотворення держави-наступниці в історичному контексті, що, на наш погляд, зможе нормативно урегулювати проблеми щодо маніпуляцій 3 територіальними зазіханнями, побудованими на так званих історичних правах одних держав на території інших, що намагається доводити у згаданій вище статті В. Путін стосовно Української Держави.

Як уже зазначалося, правовою основою режиму правонаступництва держав $\epsilon$ сукупність міжнародних і національних правових актів. Для України це:

- Статут Організації Об'єднаних Націй;

- Віденська конвенція про правонаступництво держав щодо договорів 1978 р.;

- Віденська конвенція про правонаступництво держав щодо державної власності, державних архівів та державних боргів 1983 р.;

- Закон України «Про правонаступництво України» № 1543-XII від 12 вересня $1991 \mathrm{p}$.

Зазначені міжнародні акти встановлюють універсальні правила правонаступництва і врегульовують конкретні суспільні відносини, що виникають унаслідок цих міжнародно-правових фактів, серед яких можна виділити два основних блоки: договори і майнові права. Водночас Статут ООН
[7] у ч. 2 ст. 1 визначає забезпечення принципу рівноправності та самовизначення народів однією з головних цілей Організації, на якому базується проголошення суверенітету і незалежності держав. Такі положення і положення вказаних конвенцій про поновлення державності та утворення нової держави і становлять суттєвий інтерес для дискусії щодо правонаступництва України від УРСР або попередніх українських державних утворень.

Науковці розрізняють держави, які стали правонаступниками внаслідок поновлення державного суверенітету або унаслідок створення нової держави, яка була до цього залежною від іншої держави. Так, О.Ю. Перевезенцев, на наш погляд, правильно констатує, що одними з головних особливостей фактичного (політичного) вирішення питання правонаступництва на пострадянському політико-правовому просторі виступають надання 11 державам-учасницям базових документів про створення СНД статусу держав-правонаступниць, що відділилися від колишнього СРСР, із закріпленням за ними права користуватися механізмом міжнародного правонаступництва, визначеного нормами Віденських конвенцій про правонаступництво 1978 та 1983 рр. стосовно відповідної категорії держав; з одночасним визначенням дещо особливого статусу для України та Білорусі як держав, що продовжили свою міжнародну особистість, обсяг якої розширився в результаті здобуття ними незалежності; визнання за трьома сучасними країнами Балтії - Естонією, Латвією та Литвою - статусу держав, що поновили свою первинну незалежність, у зв'язку з чим питання про правонаступництво ними міжнародно-договірних зобов'язань колишнього СРСР взагалі не ставиться [6, с. 11].

Слід зазначити, що доцільно поділяти таку позицію зазначеного вченого з урахуванням положень Віденської конвенції про правонаступництво держав щодо договорів 1978 р. [8], де у п. f) ч. 1 ст. 2 встановлено, що «..."нова незалежна держава" означає державу-спадкоємницю, територія якої безпосередньо перед моментом правонаступництва держав була залежною територією, за міжнародні відносини якої була відповідальною державапопередниця...», що також встановлено 
у п. е) ч. 1 ст. 2 Віденської конвенції про правонаступництво держав щодо державної власності, державних архівів та державних боргів 1983 р. [9].

Отож Латвія, Литва і Естонія стали державами, що поновили свою первинну незалежність, яка тривала у період 1918-1940 рр. Зазначені держави у своїх деклараціях і актах $[10 ; 11]$ максимально конкретизували факт не проголошення незалежності, а саме відновлення незалежності своїх держав, наголошуючи на російській окупації їхніх держав, на неперервність державності навіть у період окупації, коли уряди у екзилі здійснювали свою функцію в умовах еміграції тощо. Характерною ознакою поновлення державності тут $€$ аргументація щодо воєнного вторгнення та незаконної анексії, а також чітка позиція щодо відновлення державності на основі первинного акту проголошення незалежності у 1918 р.

Окрім цих балтійських держав, подібним чином визначив поновлення власної незалежності й Азербайджан, який, наприклад, у Конституційному акті [12] у ст. 2 встановив, що «...Азербайджанська Республіка $€$ наступницею існуючої з 28 травня 1918 р. по 28 квітня 1920 р. Азербайджанської Республіки». У даному акті називають окупацію Азербайджану у 1920 році армією РСФРР анексією, скасовуються всі зобов'язання за договорами, акт входження в СРСР та інші заходи, відповідальність за які покладено на країну агресора - СРСР (ст. 1-7 Конституційного акту). Абсолютно аналогічним чином було реалізовано відновлення державної незалежності Грузії на підставі Акту про незалежності Грузії від 26 травня 1918 р. 3 констатацією незаконної анексії Грузії шляхом воєнного вторгнення російськобільшовицької армії у 1921 р.

Проте ні Декларація про державний суверенітет України від 16 липня 1990 р. [13], ні Акт проголошення незалежності України від 24 серпня 1991 р. [14] не містять подібних положень, більше того, у Декларації про державний суверенітет України сама Україна згадується як Українська РСР, але вже у Акті від 24 серпня 1991 р. слід зазначити певний прогрес, де задекларовано, що Акт приймається, «...продовжуючи тисячолітню традицію державотворення в Україні...», про що також у подібному форматі згадано у преамбулі до Конституції України. У зазначених актах не сказано жодного слова про правонаступництво Української Держави від попередніх етапів державотворення, не йдеться про російсько-більшовицьку окупацію України у 1918 та 1920 рр., не йдеться про нечинність договору про входження в СРСР, про повноважність Уряду України у екзилі та інші атрибути поновлення державності.

Водночас потрібно зосередити увагу на тому, що незалежність України проголошувалась у чотири етапи у 1917-1918 рр. чотирма універсалами (певну історичну паралель можна провести у прийнятті вищезгаданих Декларації і Акту про державний суверенітет і незалежність) і так само, як у Грузії та Азербайджані і згодом у балтійських державах, була повалена воєнним вторгненням більшовицької Росії. Але ж кавказькі й балтійські держави, усвідомлюючи потребу у закріпленні міжнародно-правового факту поновлення державності, забезпечили власний суверенітет не на історичній залежності від радянського минулого, а на основі історії власного державотворення на початку XX ст.

Варто звернутися до аналогічної спроби в Україні, що була придушена нацистським окупаційним режимом у Львові, коли 30 червня 1941 р. український націоналістичний рух, а також представники громадськості проголосили Акт відновлення Української Держави і сформували Українське Державне Правління із подальшою розбудовою місцевих адміністрацій і галузевих органів виконавчої влади. Навіть в таких вкрай екстремальних політичних умовах окупації проголошення Акту здійснювалося 3 акцентом на відновлення Української Держави.

Між іншим, Закон України «Про правонаступництво України» № 1543-XII від 12 вересня 1991 р. [15] у своїх 9-ти статтях жодним чином не згадує про правонаступництво України від Української Народної Республіки періоду 1917-1918 рр., Української Держави 1918 р., гетьманату П. Скоропадського, а також об'єднаної УНР і ЗУНР 1918-1920 рр., як зробили кавказькі і балтійські держави відносно своїх попередніх державних утворень того ж 
періоду. Апеляція у цьому Законі та інших актах до різноманітних зобов'язань, що перейшли Україні від Української РСР, дає формальний привід заявляти російському Президенту В. Путіну та іншим політикам про заперечення тяглості українського державотворення, про сучасну українську державність як наслідок державного будівництва УРСР/СРСР, про Україну як продукт радянської епохи, у якій сучасна Російська Федерація визначає себе повним правонаступником, що, до речі, виразилося у цілій низці міжнародних актів, особливо щодо зовнішнього боргу СРСР тощо.

Висновки. Отже, на тридцятій річниці незалежності правонаступництво України закріплене у національному законодавстві, згідно міжнародних актів як державаспадкоємниця, територія якої безпосередньо перед моментом правонаступництва держав була залежною територією, за міжнародні відносини якої була відповідальною держава-попередниця - УРСР/СРСР, що наразі створює політико-правові проблеми і знівельовує державотворчу значимість періоду УНР і гетьманату П. Скоропадського. Політико-правові проблеми полягають у неправомірному хронологічному обмеженні існування української державності періодом з 1991 р. і по сьогодні. Таке політико-правове положення створює прецедент для обстоювання твердження про пряму залежність української державності від радянського минулого, спотворює історію української державності, негативно впливає на консолідацію українського суспільства і створює передумови для гібридних атак держави-агресора - Російської Федерації, у якій на цьому ґрунті на найвищому державному рівні формується маніпулятивна концепція щодо «єдності українського і російського народів», яка у подальшому використовується $з$ метою обґрунтування потреби у так званому «історичному возз'єднанні» цих народів, що набуває загроз анексії суверенної української території.

3 метою вирішення даної проблеми доцільним $\epsilon$ внесення змін і доповнень у преамбулу Конституції України, де за аналогією з актами балтійських і кавказьких держав потрібно сформулювати положення про правонаступництво сучасної Української Держави від українських державних утворень періоду 1917-1920 рр. Ч. 1 ст. 106 Конституції України надає право Президентові України забезпечувати правонаступництво держави, на підставі чого Голова Держави має право внести відповідний проєкт закону до українського парламенту у статусі невідкладного. Тому перспективою подальших досліджень вважаємо формування науково обґрунтованих рекомендацій щодо проєкту відповідного нормативно-правового акту.

\section{ЛITEPATУPA:}

1. Статья Владимира Путина «Об историческом единстве русских и украинцев». URL: http://kremlin.ru/events/president/news/66181

2. Історія держави та права України (1991-2019 роки) : Навчальний посібник / за заг. ред. доктора юрид. наук, професора, академіка Національної академії правових наук Бандурки О.М. Харків : Майдан, 2019. 344 с.

3. O'Connell D.P. State Succession in Municipal Law and International Law. Cambridge, 1967. Vol. 1. 592 p.

4. Craven M. The Problem of State Succession and the Identity of States Under International Law. EJIL. 1998. Vol. 9, № 1. P. 142-162.

5. Ноговіцина Ю.О. Правонаступництво держав: новий погляд на стару проблему. Вісник Київського національного університету імені Тараса Шевченка. Міжнародні відносини. 2005. Вип. 31-32. С. 121-124.

6. Перевезенцев О.Ю. Міжнародно-правове регулювання інституту правонаступництва держав щодо міжнародних договорів : автореф. дис. ... канд. юрид. наук : 12.00 .11 ; Київ. нац. ун-т ім. Т.Шевченка. Київ , 2004. 18 с.

7. Устав Организации Объединённых Наций 26 июня 1945 г. URL: https://zakon.rada.gov.ua/ laws/show/995_010\#Text

8. Віденська конвенція про правонаступництво держав щодо договорів 1978 р. URL: https://zakon.rada.gov.ua/laws/show/995_185\#Text 
9. Віденська конвенція про правонаступництво держав щодо державной власності, державних архівів та державних боргів 1983 р. URL: https://zakon.rada.gov.ua/laws/ show/995_072\#Text

10. Latvijas Padomju Sociālistiskās Republikas Augstākās Padomes Deklarācija. Par Latvijas Republikas neatkarības atjaunošanu. URL : https://likumi.lv/doc.php?id=75539

11. Акт Верховного Совета Литовской Республики О восстановлении Литовского Государства 11 марта 1990 г. № I-12 URL: https://e-seimas.Irs.It/portal/legalAct/It/TAD/TAIS.73778

12. Конституционный акт Азербайджанской республики от 18 октября 1991 г. №222-XII URL: http://base.spinform.ru/show_doc.fwx?rgn=2889

13. Декларація про державний суверенітет України від 16 липня 1990 p. URL: https:// zakon.rada.gov.ua/laws/show/55-12\#Text

14. Акт проголошення незалежності України від 24 серпня 1991 p. URL: https:// zakon.rada.gov.ua/laws/show/1427-12\#Text

15. Про правонаступництво України : Закон України від 12 вересня 1991 р. № 1543-XII. URL : https://zakon.rada.gov.ua/laws/show/1543-12\#Text 